\title{
Culture and Politics
}

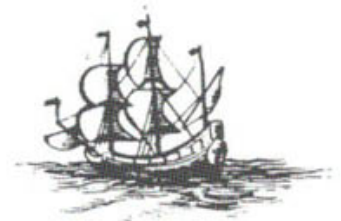

PUBLISHED UNDER THE AUSPICES OF THE

WILLIAM ANDREWS CLARK MEMORIAL LIBRARY

UNIVERSITY OF CALIFORNIA, LOS ANGELES 
Publications from the

CLARK LIBRARY PROFESSORSHIP, UCLA

1.

England in the Restoration and Early Eighteenth

Century: Essays on Culture and Society

Edited by H. T. Swedenberg, Jr.

2.

Illustrious Evidence

Approaches to English Literature of the

Early Seventeenth Century

Edited, with an Introduction, by Earl Miner

3.

The Compleat Plattmaker

Essays on Chart, Map, and Globe Making in England in the Seventeenth and Eighteenth Centuries

Edited by Norman J. W. Thrower

4.

English Literature in the Age of Disguise

Edited by Maximillian E. Novak

5.

Culture and Politics

From Puritanism to the Enlightenment

Edited by Perez Zagorin 


\title{
Culture and Politics \\ From Puritanism to the Enlightenment
}

\author{
Edited by \\ PEREZ ZAGORIN
}

Clark Library Professor, 1975-1976 
University of California Press

Berkeley and Los Angeles, California

University of California Press, Ltd.

London, England

Copyright (C) 1980 by The Regents of the University of California

ISBN 0-520-03863-0

Library of Congress Catalog Card Number 78-66078

Printed in the United States of America 